\title{
Critical success factors and green supply chain management proactivity: shedding light on the human aspects of this relationship based on cases from the Brazilian industry
}

Charbel José Chiappetta Jabbour, André Luis Mauricio \& Ana Beatriz Lopes de Sousa Jabbour

To cite this article: Charbel José Chiappetta Jabbour, André Luis Mauricio \& Ana Beatriz Lopes de Sousa Jabbour (2017) Critical success factors and green supply chain management proactivity: shedding light on the human aspects of this relationship based on cases from the Brazilian industry, Production Planning \& Control, 28:6-8, 671-683, DOI: 10.1080/09537287.2017.1309705

To link to this article: https://doi.org/10.1080/09537287.2017.1309705

Published online: 16 May 2017.

Submit your article to this journal $[\pi$

山 Article views: 393

View Crossmark data $₫$

Citing articles: 3 View citing articles 지 


\title{
Critical success factors and green supply chain management proactivity: shedding light on the human aspects of this relationship based on cases from the Brazilian industry
}

\author{
Charbel José Chiappetta Jabbour ${ }^{\mathrm{a}}$, André Luis Mauricio ${ }^{\mathrm{b}}$ and Ana Beatriz Lopes de Sousa Jabbour ${ }^{\mathrm{c}}$ \\ aStirling Management School, University of Stirling, Scotland, UK; 'b Avenue Engenheiro Edmundo Carrijo Coube (Faculty of Engineering), UNESP - \\ Univ Estadual Paulista (Sao Paulo State University), Bauru, Brazil; 'Department of Design, Manufacture and Engineering Management, University of \\ Strathclyde, Glasgow, UK
}

\section{ABSTRACT}

By applying the resources-based view (RBV) theory to green management, this study aims to analyse the relationship between critical success factors (CSFs) and the adoption of green supply chain management (GSCM) practices for some Brazil-based manufacturers of automotive batteries considered focal in their supply chains. It also analyses how human issues, known as green human resource management (GHRM) aspects, can help to increase the effectiveness of CSFs for GSCM strategies that are still not totally wellmanaged, justifying a RBV perspective. This research assumes that firms tend to be in different stages of GSCM development (more strategic or less strategic) and tests four research propositions to determine whether more proactive GSCM is related to higher levels of effectively managed CSFs. Three focal companies that operate in the Brazilian automotive battery industry were studied. Research results suggest that more proactive GSCM practices correlate to more effectively managed CSFs and to a greater support from GHRM. We argue that managers with a clear GHRM strategy will have more success in GSCM adoption, using more green training, green recruitment and selection, green performance evaluation and employee rewards.
ARTICLE HISTORY

Received 20 June 2014

Accepted 12 January 2015

\section{KEYWORDS}

Green supply chain management; critical success factors; green human resource management; green operations management; resources-based view; sustainable operations; Brazil

\section{Introduction}

Taking into account that sustainability is a core theme of the future of manufacturing (Garetti, Mummolo, and Taisch 2012), an increasing number of organisations are interested in managing the sustainability of their internal and external operations along entire supply chains (Walker et al. 2014). Thus, sustainability is part of the current state of operations management (Ageron, Gunasekaran, and Spalanzani. 2012; Gunasekaran, Irani, and Papadopoulos 2014; Gunasekaran and Ngai 2012). Accordingly, green supply chain management (GSCM) emerges as strategic approach (Govindan et al. 2014a) because it integrates the principles of environmental management with supply chain management activities, allowing organisations to reconcile economic and environmental objectives (Muduli et al. 2013).

The resources-based view (RBV) is a well-established theory affirming that companies may increase their competitiveness by developing critical resources and capabilities (Barney 2001). The RBV can be applied to understand the greening of companies (Hart and Dowell 2011) because it is one of the most-adopted theoretical lenses in analysing supply chain management (Carter et al. 2014). However, there is still a lack of research integrating RBV for identifying the critical factors that can support organisations' implementation of GSCM. RBV can also support a better understanding of how human aspects can promote CSFs for GSCM adoption. This discussion may help managers to understand internal issues in their companies when adopting GSCM practices. Integration between RBV and GSCM could be considered as a theoretical gap and it remains one of the most significant deficiencies in the GSCM literature (Sarkis, Zhu, and Lai 2011).

In this context, CSFs are the organisational actions necessary to ensure success and competitiveness, thus supporting a company's organisational change process (Rockart 1978). Therefore, it is important to identify, analyse, monitor and address those actions in the pursuit of continuous improvement (Boynton and Zmud 1984; Hu and Hsu 2010; Leidecker and Bruno 1984; Rockart 1978). For example, CSFs must be effectively managed for companies to become greener and thereby achieve a better fit between 'plan' and 'achievement' when adopting green practices (Wijen 2014) such as GSCM. Discovering critical issues in green management is relevant to understanding specific valuable resources (Mittal and Sangwan 2014).

However, many CSFs continue to hinder companies' adoption of GSCM (Testa and Iraldo 2010); therefore, they must be identified and effectively managed to ensure the successful implementation of GSCM practices (Govindan et al. 2014b; Muduli et al. 2013). The literature argues that firms can be positioned in different stages 
of GSCM development, from a non-strategic level to a strategic one (Carbone and Moatti 2011). In this context, understanding CSFs is relevant for analysing why some firms are more proactive than others in terms of GSCM.

The literature on CSFs has explored themes such as the relationship between CSFs and the adoption of environmental management systems, or EMS (Babakri, Bennett, and Franchetti 2003; Hui, Chan, and Pun 2001; Quazi 1999; Sambasivan and Fei 2008; Zutshi and Sohal 2004), indicating that when CSFs are not well managed, they tend to become barriers. There are emerging studies attempting to relate CSFs and GSCM, such as those of $\mathrm{Hu}$ and Hsu (2010), Kim and Rhee (2012), Ab Talib and Muniandy (2013), and Luthra et al. (2014), which aim to identify the CSFs that favour the adoption of GSCM practices. However, an emerging theory that appeals to the 'human side of corporate sustainability', called green human resource management (GHRM) (Jackson, Schuler, and Jiang 2014; Jackson et al. 2011), has not yet been related to CSFs and GSCM.

This new point of view can be relevant to overcoming one of the main current gaps in the state of GSCM: a clearer link between RBV (Barney 2001) and GSCM theory (Sarkis, Zhu, and Lai 2011), with the aim of identifying CSFs that can contribute to better greening of firms. As affirmed by Sarkis, Zhu, and Lai (2011), the identification of critical resources that can help companies in the external-internal adjustment can be an original research line in GSCM theory. Knowing factors and barriers to GSCM implementation are critical is useful for greening companies (Mittal and Sangwan 2014) and may explain why firms tend to have different levels of GSCM development (Carbone and Moatti 2011).

In this context, GHRM is essential for the implementation of GSCM (Luthra et al. 2011; Mathiyazhagan et al. 2013). We highlight GHRM, which involves aligning human resources (HR) aspects and environmental management through recruiting, training, evaluating performance and rewards focused on environmental issues. These aspects are not only duties of HR departments but are conducted by any line managers who lead teams. GHRM provides a great deal of synergy with the concept of CSFs, and both can improve the greening of businesses (Jabbour 2013; Jabbour, Teixeira, and Jabbour 2013; Renwick, Redman, and Maguire 2013; Longoni, Golini, and Cagliano, 2014).

Considering that CSFs must be managed to facilitate more sustainable organisations (Grimm, Hofstetter, and Sarkis 2014) and that the successful adoption of GSCM and GHRM can support this process, particularly in highly polluting industrial sectors such as automotive batteries, the questions that motivates this study are: how have some Brazilian companies in the automotive battery industry that are focal in their supply chains managed CSFs related to the adoption of GSCM; and how can GHRM aspects improve the management of not-yet-effectively managed CSFs, helping these companies to increase their GSCM proactivity levels? Consequently, considering that firms tend to achieve different levels of proactivity in GSCM, this work aims to identify the effectiveness of CSFs during the adoption of GSCM, discussing the potential role of GHRM in improving that process, based on an RBV-GSCM theoretical angle (Sarkis, Zhu, and Lai 2011). The focus on RBV may be useful to identify CSFs that can explain the current GSCM levels of the studied companies.

The focus on Brazil-based companies is justified by the fact that this country is one of the top 10 largest economies in the world, and it is the Latin America's country with the largest number of organisations certified by ISO 14001 (CIA 2012; Jabbour 2013). Brazilian manufacturers need to deal with new environmental legislation and pressures to establish sustainable operations (Jabbour et al. 2014). Also, research on sustainability in emerging economies such as Brazil's should be increased (Gunasekaran, Jabbour, and Jabbour 2014). The focus on the automotive production chain is justified because, according to Diabat, Khodaverdi, and Olfat (2013), there is a need for studies on the automotive supply chain and therefore the battery industry, because it has a high environmental impact (Matheys et al. 2009). Brazil can also be considered an appropriate context because, like China and other emerging economies, it is setting up new environmental legislation, such as the Brazilian New Policy on Solid Waste (BNPSW) (Jabbour et al. 2014), that can mandate the corporate adoption of green thinking.

A case study approach was adopted because the literature on green supply chains needs more in-depth qualitative research (Genovese et al. 2014; Pagell and Shevchenko 2014; Subramanian et al. 2014; Wolf 2011); at this moment, the creation of more sustainable supply chains remains one of the great challenges for businesses (O'Rourke 2014). Three focal and pertinent companies to understanding GSCM diffusion (Lee et al. 2014b) were examined in this work. This methodological approach was selected because there is a need for more qualitative research with an exploratory purpose in the current body of knowledge on supply chain management (Carter et al. 2014).

This article is structured as follows: Section 2 presents the theoretical framework, divided between GSCM and CSFs (Section 2.1) and GHRM (Section 2.2), and develops four main research propositions that will be analysed in light of case study evidence; Section 3 describes the research methodology; Section 4 explains the results; and Section 5 presents discussion. Finally, Section 6 clarifies this study's final conclusions and implications.

\section{Conceptual background and research prepositions development}

\subsection{Critical success factors (CSFs) for the adoption of GSCM}

Based on the RBV, GSCM can make an organisation more competitive, but it is also dependent on relevant and critical organisational resources (Sarkis, Zhu, and Lai 2011). GSCM concerns the insertion of 'green' issues into the supply chain (Srivastava 2007; Zhu, Tian, and Sarkis 2012), with the joint effort of all tiers of a supply chain in developing processes, products and services that address environmental concerns (Green et al. 2012). GSCM principles have become important strategies for companies to achieve profit and gain market share by lowering their environmental impacts and increasing efficiency (Büyüközkan and Çifçi 2012). For example, Lee et al. (2015), based on a survey of ISO 14001-certified companies in Malaysia, revealed the existence of a positive and significant linkage between green suppliers and the competitiveness of firms. GSCM practices are actions (Golicic and Smith 2013) that can reduce the environmental impacts of companies' activities without sacrificing quality, productivity or operating costs. GSCM practices include internal environmental management, green purchasing, cooperation with customers, 
ecodesign and investment recovery (Zhu, Sarkis, and Lai 2008). Based on studies by Srivastava (2007) and Sarkis, Zhu, and Lai (2011), reverse logistics is also considered a GSCM practice. GSCM practices are not easy to adopt and implement due to the presence of several barriers (Govindan et al. 2014b; Muduli et al. 2013), and can vary between firms in the same country (Mohanty and Prakash 2014; Zhu, Tian, and Sarkis 2012).

The greening of supply chains remains one of the most relevant challenges for business managers, and there are critical factors that should be further researched to become realities (O'Rourke 2014). Therefore, it is essential to identify and evaluate the CSFs for GSCM practices. The identification of CSFs could be analysed in light of RBV (Barney 2001) considering the natural environment (Hart and Dowell 2011). According to Sarkis, Zhu, and Lai (2011), there is a significant gap in the GSCM literature on how critical factors and resources can support the greening of the supply chain process. Shedding light on these critical factors can help managers in emerging economies to achieve a better fit between 'means' (adoption of GSCM practices) and 'ends' (outcomes) and avoid the'means-ends decoupling' phenomenon (Wijen 2014). Consequently, Luthra et al. (2014) affirm that a better understanding of critical factors for GSCM can be relevant to practitioners, managers, customers and governments aiming to contribute to sustainability.

CSFs can be useful to explain why some firms are positioned into different stages or maturity levels of GSCM. According to Carbone and Moatti (2011), firms generally can be classified in different stages of GSCM maturity. In this research, based on Carbone and Moatti (2011), we consider three points or levels of maturity for discussing the strategic orientation of firms regarding GSCM.

- More Proactive GSCM: These firms have a long-term, proactive, and clear approach to environmental management and have implemented a green supply chain strategy, and they have done so with respect to the different phases of the supply chain (raw material extraction, sourcing, product design, manufacturing, forward and reverse logistics). This type of firm is recognised by corporate leadership focused on greener products, process innovations and corporate image in the full adoption of GSCM practices.

- Partially Proactive GSCM: Firms in this group are trying to improve their GSCM towards a more strategic approach but they have not yet fully adopted GSCM.

- Less Proactive GSCM: Firms from this group have become interested in environmental issues more recently, following other leading actors in the same competitive environment. These firms perceive an environmental regulatory framework as a real constraint for the core activities of their companies, and are therefore less proactive when managing their GSCM. In this case, the most compelling rationales for a green supply chain strategy are cost reduction and process optimisation. Adoption of GSCM practices is lower than the other groups.

Based on the different possible stages of GSCM and from an RBV perspective, CSFs are aspects that must be managed effectively to ensure that an organisation achieves its objectives (Rockart 1978). In principle, as stated above, studying CSFs can provide an organisation with a map of its strengths and weaknesses with an eye toward continuous improvement (Leidecker and Bruno 1984), thus rendering CSFs as vital to strategic and operational management (Boynton and Zmud 1984).

In this sense, the identification of CSFs for GSCM allows managers to better understand GSCM practices and to have a clearer understanding of their organisational situations ( $\mathrm{Hu}$ and $\mathrm{Hsu}$ 2010). In this research, the adopted CSFs are those suggested by Wee and Quazi (2005), as shown in Table 1.

Studies associating CSFs and GSCM are still being developed, including studies by $\mathrm{Hu}$ and Hsu (2010) and Ab Talib and Muniandy (2013), which have identified and presented a set of CSFs for the implementation of GSCM practices; studies by Kim and Rhee (2012) and Luthra et al. (2014), which have identified and analysed CSFs for adopting GSCM practices and the resulting increase in organisational performance; and a study by Bhattacharya et al. (2014), which discovered that organisational commitment - based on top management commitment, middle management commitment, cross-functional commitment and employee involvement - is a key issue when discussing green supply chain implementation.

As many CSFs to GSCM implementation are related to human aspects, a better relationship between CSFs and GSCM can be supported by a new and emerging literature focused on GHRM.

As a consequence of this literature review, following research propositions are put forward:

Proposition 1: Companies with more proactive GSCM approaches will also have better-managed CSFs;

Proposition 2: Companies with less proactive GSCM approaches will also have less well-managed CSFs.

\subsection{Linking GHRM, CSFs and GSCM}

Drawing on the RBV theory and its implications for HR management (Saá-Pérez and Garcla-FalcÓn 2002), it is possible to argue that HR is relevant to firms' outcomes and should be better linked with operations management (Boudreau et al. 2003; Croson et al. 2013; Santos 2000). Since the 1980s, Schuler and Jackson (1987) have argued that HR must be aligned to firms' strategies and that this alignment should apply to line managers as well as HR managers. UrtasunAlonso et al. (2014) affirm that HR aspects are still relevant to manufacturing strategies.

Considering the traditional concept of HR management (Sudin 2011) and its continuing relevance to firms, GHRM is the alignment of HR management strategies with the goals of an organisation's environmental management plan. It includes practices related to environmental issues, such as (Jabbour 2013; Jabbour, Teixeira, and Jabbour 2013; Jabbour et al. 2012; Renwick, Redman, and Maguire. 2008):

- green recruitment and selection;

- green training;

- green performance evaluation; and

- green rewards.

These aspects should be utilised by anyone involved in leading teams and employees and aiming at greener behaviour in the workplace (Kim et al. 2014). 
Table 1. Critical success factors (CSFs) for GSCM adopted in this research.

Critical success factors

(Adapted from Wee and

Quazi, 2005)

Information management

Measurement

Top Management Commitment

Supplier management

Training

Competencies for greener products \& processes
Definitions

Characterised by an effective information management system for the collection and maintenance of environmenta information. One major obstacle is a lack of knowledge and information sharing. Appropriate hardware and software are required

The involvement of collaborators can minimise resistance to and lack of concern for environmental issues. Collaborators mus be encouraged and be provided the opportunity to present and implement their own suggestions and be recognised for them. Multidisciplinary teams or green teams are created to solve environmental problems. Managers' involvement is essential to cultural change and the creation of a corporate culture, through training and team spirit, able to provide better synergy

Environmental aspects and impacts for risk assessment are measured, environmental goals and objectives are set, and a cost-benefit analysis is performed for guidance

Senior management support and leadership are vital to ensure awareness, understanding, and commitment to the implementation of an environmental vision and corporate policy throughout the organisation. Financial support and an adequate supply of resources should be provided. Strategic planning should incorporate environmental issues and the organisation should participate in environmental projects and the construction of a culture that considers knowledge a vital organisational resource. The commitment of senior management is necessary for the success of GSCM programmes

Education, training and awareness regarding environmental issues, environmental audits, the exigency of an EMS and certifications are necessary for supplier management. The involvement of suppliers during the environmental process/ product development stage is essential

The successful implementation of an EMS depends on the training and learning of all collaborators and stakeholders to improve skills, enhance competence, promote environmental awareness, and educate employees about the use of tools and environmental practices. It is very important to provide resources and to identify necessary training needs

Competencies for focusing on minimising impacts on the environment, analysing the product life cycle, taking a preventive approach, and integrating environmental concerns are crucial. Competencies must include changing existing processes and products that should be redesigned to reduce waste, power consumption and emissions
Other references for definition's support

Quazi (1999), Babakri, Bennett, and Franchetti (2003), Zutshi and Sohal (2004), Ngai, Cheng, and Ho (2004), Ogden (2006), Tumamala et al. (2006), Sambasivan and Fei (2008), Chin, Chan, and Lam (2008), Hu and Hsu (2010), Sarkis (2012), Routroy and Pradhan (2013)

Quazi (1999), Hui, Chan, and Pun (2001), Babakri, Bennett, and Franchetti (2003), Zutshi and Sohal (2004), Ngai, Cheng, and Ho (2004), Ogden (2006), Tumamala et al. (2006), Sambasivan and Fei (2008), Hu and Hsu (2010), Bhattacharya et al. (2014)

Babakri, Bennett, and Franchetti (2003), Zutshi and Sohal (2004), Tumamala et al. (2006), Sambasivan and Fei (2008), Hu and Hsu (2010)

Quazi (1999), Babakri, Bennett, and Franchetti (2003), Zutshi and Sohal (2004), Ngai, Cheng, and Ho (2004), Ogden (2006), Sambasivan and Fei (2008), Chin, Chan, and Lam (2008), Hu and Hsu (2010), Routroy and Pradhan (2013), Patil and Kant (2013), Bhattacharya et al. (2014)

Quazi (1999), Zutshi and Sohal (2004), Tumamala et al. (2006) Jabbour and Jabbour (2009), Hu and Hsu (2010), Lee et al. (2015)

Babakri, Bennett, and Franchetti (2003), Zutshi and Sohal (2004), Sambasivan and Fei (2008), Hu and Hsu (2010), Sarkis, Gonzalez-Torre, and Adenso-Diaz (2010), Patil and Kant (2013), Jabbour, Teixeira, and Jabbour (2013)

Zutshi and Sohal (2004), Sambasivan and Fei (2008), Hu and Hsu (2010)
According to Paillé et al. (2013), the adoption of GHRM can improve a company's environmental performance and motivate employees, and this motivation can generate sources of competitive advantage. GHRM has the potential to positively contribute to both the welfare of employees and the improvement of environmental performance (Renwick, Redman, and Maguire 2013). For example, based on data from German companies, Wolf (2013) discovered that the implementation of sustainability measures is positively related to firm performance and that employee integration moderates this relationship.

Organisations aiming for good environmental management, including the adoption of GSCM practices, should emphasise environmental issues in the recruitment and selection of employees who are willing to engage with environmental issues (Renwick, Redman, and Maguire 2013). Understanding the organisation's green culture and its environmental values represents a part of the recruitment practices of environmental management (Jackson et al. 2011).

One of the pillars of GHRM is green training (Jabbour 2013; Jabbour, Teixeira, and Jabbour 2013; Renwick, Redman, and
Maguire 2013). Training should focus on environmental awareness, cultural change and the development of technical and management skills (Sudin 2011). Developing a base of environmental knowledge is the key to effective environmental training (Renwick, Redman, and Maguire 2013; Mohanty and Prakash 2014).

Green performance evaluation is another aspect of GHRM (Jabbour, Santos, and Nagano 2010). Performance management and evaluation are challenges for employee engagement in environmental management (Renwick, Redman, and Maguire 2013).

However, little is known about how GHRM can synergistically support the effective management of CSFs necessary for the adoption of GSCM practices, and we must go beyond the existing conceptual discussions in order to investigate this relationship (Saturnino and Jabbour 2010). Lengnick-Hall, Lengnick-Hall, and Rigsbee (2013) consider the general integration of HR and SCM to be a still-neglected area of research.

Based on this literature review, it is possible to suggest two more research propositions: 
Proposition 3: Companies with a more strategic GSCM approach and well-managed CSFs will also have more supportive GHRM aspects.

Proposition 4: Companies with a less strategic GSCM approach and less well-managed CSFs will also have less supportive GHRM aspects.

\section{Research methodology}

Searches recently conducted on scientific databases (ISI Web of Science and Scopus) reveal that there is no research integrating GSCM, CSFs and GHRM aspects in the Brazilian context in light of the RBV theory, as proposed here. Consequently, a case can be made for an exploratory, qualitative research based on the multiple case study strategy (Yin 2009). According to Kim and Rhee (2012), there is a need to conduct qualitative case studies to better understand CSFs in GSCM. Pagell and Shevchenko (2014) also affirm that more qualitative, in-depth research is necessary to understand the 'how' of more sustainable supply chain management. In the same line, Carter et al. (2014) agree that qualitative and exploratory studies are scarce in the field of research on supply chain management. Because of these literature gaps, this research is based on a qualitative approach with evidence from an emerging economy, which is also needed (Gunasekaran, Jabbour and Jabbour, 2014). The four research propositions that have emerged from the literature review were not yet tested, confirming the opportunity for a qualitative, exploratory study.

The companies analysed in this research are three of the 10 most-important automotive battery companies in Brazil, which are focal in their supply chains and are experiencing strong pressure from Brazilian environmental legislation (Castro, Barros, and Veiga 2013; Jabbour et al. 2014). This indicates a proper context for the study of GSCM (Koplin, Seuring, and Mesterharm 2007; Seuring and Müller 2008), mainly because focal companies are relevant to GSCM diffusion (Lee et al. 2014b). The study of an emerging economy such as Brazil's that is shaping its environmental legislation is an interesting case to analyse critical factors that can reduce the'means-end decoupling' phenomenon (Wijen 2014). Selecting Brazil can also add new insights to the literature because most of the recent research in GSCM focuses on China (Zhu, Tian, and Sarkis 2012) and India (Mohanty and Prakash 2014). The study of green issues concerning pollution in Latin America is suggested by Vazquez-Brust and Liston-Heyes (2010).

Battery manufacturers are part of the automotive sector that exerts a great influence on the Brazilian economy, with a $21 \%$ share of industrial gross domestic product (GDP) and a 5\% share of total GDP (Anfavea 2014).

We have chosen to study the following companies: (1) a large ISO 14001 company, because large companies direct more effort and attention to green issues (González-Benito and GonzálezBenito 2006); (2) a medium-sized company with ISO 14001; and (3) a medium-sized company looking for ISO 14001. According to Mohanty and Prakash (2014), it is interesting to study firms of diverse sizes. These companies are called A, B and C, respectively, and their primary focus is the production of lead-acid batteries for the automotive sector; this type of battery has a high environmental impact (Matheys et al. 2009).

Cases were analysed based on the research framework as seen in Figure 1, with the intention of understanding the relationship of CSFs to the adoption of GSCM practices, and how GHRM can collaborate with the effective administration of improperly managed CSFs. It is assumed that CSFs support GSCM practices at various levels of effectiveness and that various GHRM practices may contribute to increasing the level of effective CSF management by GSCM.

For data collection, a script of interviews with three distinct parts was developed: (1) characterisation of the companies, (2) evaluation of CSFs for the adoption of GSCM practices and (3) discussion of GHRM practices relevant to the effective management of CSFs.

Data were collected through personal interviews, with a primary focus on environmental managers because, according to Green et al. (2012), it is necessary to choose managers with knowledge in GSCM practices. In each company, environmental managers, quality managers, project managers and purchasing managers were interviewed. Additionally, data were collected from observations at the sites of operating activities and by obtaining secondary data (companies' websites, documents, reports) with the objective of improving the validity of this research.

Table 2 presents the sources of the information collected for the case study. Data analysis was performed by crossing cases to identify the relationships among sources of evidence and also by triangulating data obtained from direct observations and secondary data.

Conclusions were drawn based on the sources of convergent analyses, comparing them with theory (Voss, Tsikriktsis, and Frohlich 2002). Categories with each GSCM maturity level, CSFs and GHRM aspects were considered. First, Companies A, B and $C$ were classified according to the degree of their proactive approach to GSCM, and the effectiveness of their CSF management for the adoption of GSCM. Finally, we determined how GHRM had supported that process. Results are presented along with some excerpts from the interviewees.

Crossing the companies' classifications in the levels of GSCM, CSFs adoption and GHRM aspects, it is possible to systematise the research results and test the propositions that emerged from the literature review.

\section{Results}

\subsection{Green supply chain management (GSCM) in the studied cases}

The GSCM practice of internal environmental management is performed in companies A and B mainly by ISO 14001. Company C is pursuing the EMS certification. As the battery industry is very polluting, there is great concern about the adequacy of internal operations and environmental legislation. 'It is important to verify that all environmental legislation was raised and fulfilled' (environmental manager, company A). In this context, previous experience with ISO9001 is relevant, since 'some requirements of ISO 14001 and ISO 9001 are very similar' (environmental manager, company $\mathrm{C}$ ). The strengthening of internal environmental management occurs through the dissemination of environmental policy, the creation of environmental performance indicators, employee involvement and environmental audits.

On green purchasing, companies A, B and C have criteria with environmental requirements that are used to inform suppliers. 


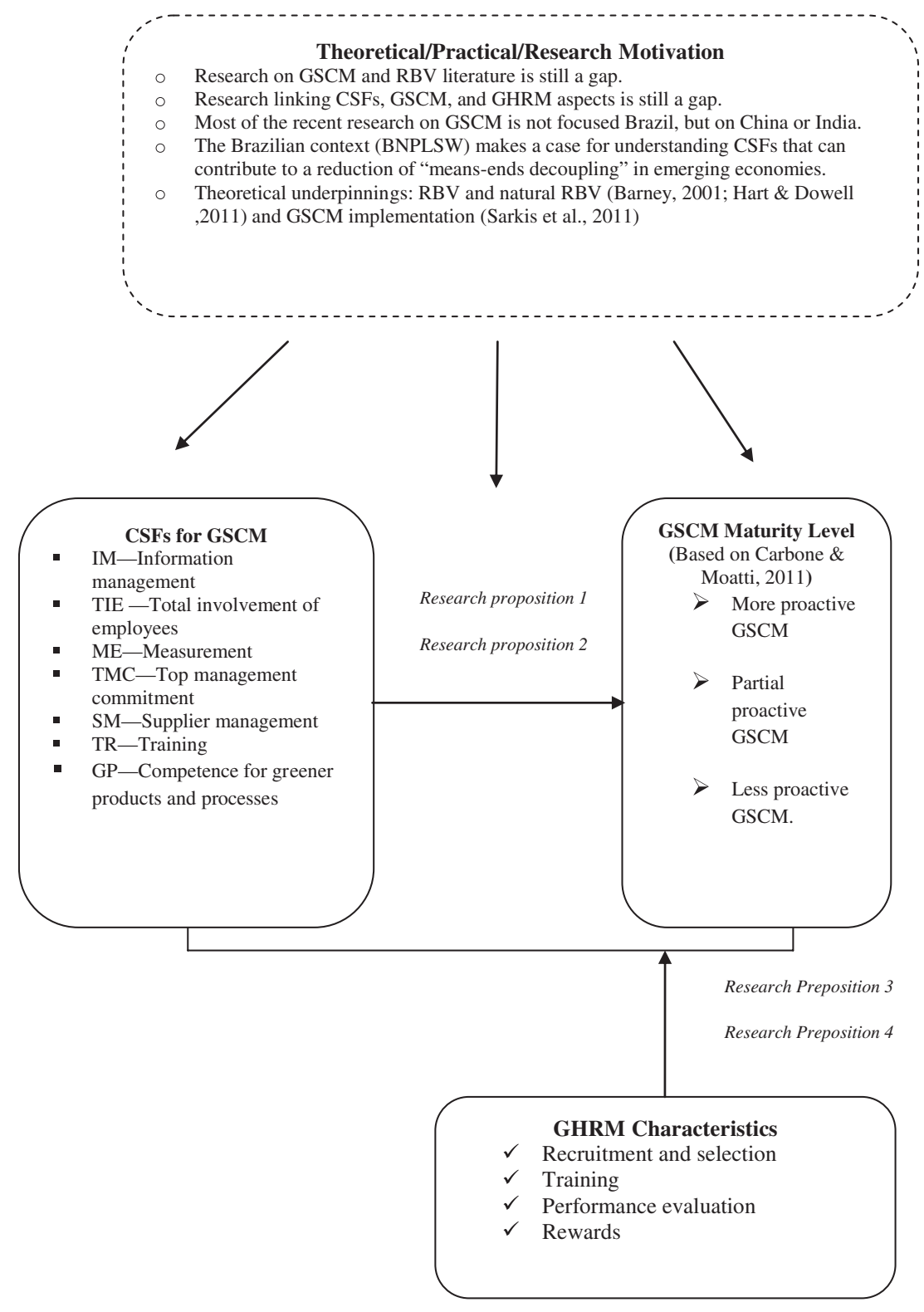

Figure 1. Research framework.

The main inputs for the manufacture of an automotive battery, which are part of green purchasing and may cause a significant environmental impact, are lead, sulphuric acid, boxes and plastic caps, polyethylene separators and stickers. So it is a matter of interest to have environmentally sound suppliers. For example, in company $A$ there is an environmental workshop with environmental awards for suppliers. In company B, the environmental dimension is integrated in the quality manual for suppliers.

The GSCM practice of cooperation with customers is adopted and more closely integrated with distributors and automakers and not with final consumers; this fact is due to the existence of rules and laws that determine the product specifications and handling care. There was no evidence of effective cooperation with final customers to develop cleaner processes and use less resource during those processes, but there was a strong concern with compliance with legislation. 'Automotive assemblers demand that environmental law is enforced' (quality manager, company A). According to a project manager at company B, in a business-to-business context, 'If the environment is valued by the consumers, they will require it of us ... many customers want to collaborate in helping to develop environmentally improved products'.

In regard to Ecodesign, the goal for all companies is 'doing more with less' (quality manager, company A); none of the companies has adopted life cycle assessment. Currently, company $A$ is focusing on drastically reducing energy savings during both production and the operation of its batteries. Company B was able to reduce up to $8 \%$ its consumption of lead and is applying an integrated approach they call 'lean and green'. In company C, the focus is on reducing costs once the other issues are specified by law: 'Government will require the seal suitability for the commercialization of batteries ... from the product manufacturing to the reverse logistics processes will be analysed' (project manager, company C). 
Table 2. Data collection process/sources - multiple case studies.

Sources of evidence

\begin{tabular}{|c|c|c|c|}
\hline Sources & Case A & Case B & Case C \\
\hline $\begin{array}{l}\text { Company's } \\
\text { Characterisation }\end{array}$ & $\begin{array}{l}\text { - Multinational company that has operated } \\
\text { in the market for more than } 80 \text { years and } \\
\text { has approximately } 1300 \text { employees. Primary } \\
\text { supplier of batteries for automakers; also a } \\
\text { presence in the aftermarket }\end{array}$ & $\begin{array}{l}\text { - National Company that has operated in } \\
\text { the market for more than } 21 \text { years and has } \\
\text { approximately } 500 \text { employees. Sells to the } \\
\text { aftermarket, exporters and automakers }\end{array}$ & $\begin{array}{l}\text { - National Company that has operated in } \\
\text { the market for more than } 50 \text { years and has } \\
\text { approximately } 505 \text { employees. Focused on } \\
\text { aftermarket and export, with the automak- } \\
\text { ers as targets }\end{array}$ \\
\hline Interviews & $\begin{array}{l}\text { - Contact accomplished in three steps, two via } \\
\text { phone and one visit to the company, with a } \\
\text { total duration of approximately six hours } \\
\text { - Interview with the environmental manager, } \\
\text { who has worked at the company for } 22 \text { years } \\
\text { - Interview with the quality engineer, who has } \\
\text { worked at the company for six years. } \\
\text { - Interview with the purchasing manager, who } \\
\text { has worked at the company for seven years. } \\
\text { - Interviews were conducted using a script, } \\
\text { and were audio taped for transcription and } \\
\text { analysis. }\end{array}$ & $\begin{array}{l}\text { - Contact accomplished in six stages, three via } \\
\text { phone and three visits to the company, with } \\
\text { a total approximate duration of three and } \\
\text { one-half hours } \\
\text { - Interview with a human resources/environ- } \\
\text { mental manager, who has worked at the } \\
\text { company for } 19 \text { years } \\
\text { - Interview with the project manager/man- } \\
\text { agement representative, who has worked at } \\
\text { the company for } 21 \text { years } \\
\text { - Interview with the purchasing manag- } \\
\text { er, who has worked at the company for } \\
18 \text { years } \\
\text { - Interviews were conducted using a script } \\
\text { and were audio taped for transcription and } \\
\text { analysis }\end{array}$ & $\begin{array}{l}\text { - Contact accomplished in four stages, two } \\
\text { via phone and two visits to the company, } \\
\text { with a total duration of approximately four } \\
\text { hours } \\
\text { - Interview with the environmental man- } \\
\text { ager, who has worked at the company for } \\
18 \text { months (environmental eng.) } \\
\text { - Interview with the supply manager, who } \\
\text { has worked at the company for } 14 \text { years } \\
\text { (civil eng.) } \\
\text { - Interview with the quality control super- } \\
\text { visor, who has worked at the company for } \\
25 \text { years. } \\
\text { - Interviews were conducted using a script } \\
\text { and were audio taped for transcription and } \\
\text { analysis. }\end{array}$ \\
\hline $\begin{array}{l}\text { Notes - direct } \\
\text { observation }\end{array}$ & $\begin{array}{l}\text { - One visit for interviews } \\
\text { - One technical visit (observing air filtration } \\
\text { systems, dust collectors for analysis, monitor- } \\
\text { ing stations for air quality and others) }\end{array}$ & $\begin{array}{l}\text { - Three visits for interviews } \\
\text { - One technical visit (observing air filtration } \\
\text { systems, dust collectors for analysis, air } \\
\text { quality monitoring stations, groundwater } \\
\text { monitoring and soil/vegetation monitoring) }\end{array}$ & $\begin{array}{l}\text { - Two visits for interviews } \\
\text { - One technical visit (observing air filtration } \\
\text { systems, dust collectors for analysis, air } \\
\text { quality monitoring, soil/vegetation moni- } \\
\text { toring and recycling centre) }\end{array}$ \\
\hline
\end{tabular}

Regarding investment recovery, all companies are optimising their systems of planning and controlling production to avoid losses. Each has an area for storing unserviceable items that are sold to other organisations.

Finally, reverse logistics is intensely adopted by companies for two reasons: (1) it is possible to reuse or recycle almost all components of the batteries, and (2) Brazilian law has, since 2008, forced retailers to accept used batteries, sending them to the manufacturers. This pressure is higher than before due to the BNPSW. 'Reverse logistics allows us to put into practice our sustainability strategy' (environmental manager, company A).

Based on the previous discussion on maturity levels of GSCM, it is possible to classify these companies along the continuum of GSCM approaches from 'less proactive' to 'more proactive'. In this context, following the arguments above, the following classifications are proposed:

- More proactive GSCM: Company A, mainly because this is the oldest company with a consistent adoption of ISO 14001. It is investing in green product and process design along the supply chain through an ecodesign approach; it is investing on reverse logistics; and there are more structured actions for green purchasing. This is the company with more GSCM activities and it is the most evidence-based GSCM;
- Partially/intermediate proactive GSCM: Company B, mainly because it is adopting many practices of GSCM, but its ISO14001 is still maturing and ecodesign is not clearly implemented. There is a clear intention for improving GSCM, but it is not fully evidence-based;

- Less proactive GSCM: Company C, mainly because it is just now seeking an EMS certification. This company has adopted fewer principles of GSCM compared with companies A and B.

Thus, proactive GSCM is more intense for company A, intermediate for company $B$ and less intense for company $C$.

\subsection{Critical success factors (CSFs) for GSCM}

Table 3 demonstrates the effectiveness of CSF implementation/ management for the adoption of GSCM in the studied organisations. Among the widely cited CSFs, top management commitment and supplier management are effectively managed. The CSF of information management is properly managed, except in company C. The CSF of total involvement of employees is partially managed in companies $A$ and $C$, and it is effectively managed in company $\mathrm{B}$. The CSF of measurement is effectively managed in companies $A$ and $B$ and is partially managed in company $C$. The CSF of training is partially managed in all the studied companies. The CSF of competence for greener products and processes 
Table 3. Levels of management of critical success factors.

\begin{tabular}{lccccccc}
\hline & \multicolumn{7}{c}{ Critical success factors } \\
\cline { 2 - 7 } Companies & IM & TIE & ME & TMC & SM & TR & GP \\
\hline A & 0 & $O$ & 0 & 0 & 0 & 0 & 0 \\
B & 0 & 0 & 0 & 0 & 0 & 0 & 0 \\
C & 0 & 0 & 0 & 0 & 0 & 0 & 0 \\
\hline
\end{tabular}

Notes: effectively managed $\bigcirc$ partially managed $\bigcirc$ not yet well managed. IM Information Management, TIE - Total Involvement of Employees, ME - Measurement, TMC - Top Management Commitment, SM - Supplier Management, TR Training, GP - Competence for Greener Product \& Process.

is effectively managed in company A, partially managed in company $B$ and unmanaged in company $C$.

Some CSFs are effectively managed and therefore are not featured in this section because its analytical focus is on those CSFs that can be improved through GHRM actions. Table 3 shows that the CSFs that are not yet effective and require attention include full employee involvement, training and competence for greener products and processes.

The CSF of information management is partially effective and has an influence on the GSCM practices of green purchasing, ecodesign and reverse logistics in company $C$. This is due to the need to develop channels of communication that account for the entire supply chain. A database with information related to environmental matters for all processes is in an early development stage, and there remains a need for a better flow of information not limited to a single department. The environmental manager of company $C$ stated that 'the lack of knowledge in the supply chain creates barriers to information sharing because they ask for evidence without knowing what they really want'.

The CSF of measurement is partially effective and has an influence on the GSCM practices of internal environmental management, green purchasing and reverse logistics in company $\mathrm{C}$. This CSF has not been well managed due to the implementation of an EMS in which indicators are inserted into the processes, the fact that tools for measuring environmental aspects and their impacts on risk assessment are in development, and the fact that the systems for verifying investment recovery and reverse logistics are in progress.

The CSF of competence for greener products and processes successfully-managed in A partially well managed and influences the GSCM practice of investment recovery in company B. To be fully-achievable, this CSF requires implementation of a product life cycle analysis. With respect to company $\mathrm{C}$, the CSF of competence for greener products and processes has not been fully-developed, and it has influence on the GSCM practice of ecodesign. The justification for this is that company C is still seeking ISO 14001 certification, and implementation of certain environmental practices is in the early stages. The CSFs of training and total involvement of employees may become potential future barriers to GSCM because they are not effectively managed.

A cross-case analysis show that both companies $A$ and $B$ tend to be more advanced in managing CSFs; however, company $A$ is the only one to achieve solid management of the CSF of competence for greener products and processes. This CSF is distinctive and can explain why company $A$ is better than companies $B$ and $C$ in terms of GSCM. Company $C$ is the worst in terms of an effective management of CSFs for GSCM. Thus, in ranking the management of CSFs for GSCM, it is more successful in company $A$, followed by company $B$, and finally by company $C$, respectively.

\subsection{The role of GHRM in the effective management of CSFs for GSCM}

One way to improve the effective management of the CSFs for GSCM is by adopting GHRM practices, as suggested by all respondents from companies $\mathrm{A}, \mathrm{B}$ and $\mathrm{C}$.

The green training in company $A$ is conducted by the environmental manager himself, while the HR Department is involved in providing the structure and conditions for the training to be performed. In company $C$, green trainings are conducted by a social worker without the involvement of the HR department. In company $\mathrm{B}$, there is a training department. In none of these cases does the HR department foster environmental awareness. The primary difficulties related to training are as follows: inducing supervisors to free up employee work time for training, the lack of a measurement to verify the effectiveness of training, a lack of depth in the subjects covered in training and the lack of continuous green training. Thus, attention to GHRM, providing green training, can help to improve this process.

None of these organisations have strategies for greener recruitment and selection of employees. Environmental requirements are included in job descriptions only when those jobs involve tasks related to the environment or that may cause environmental impacts. There is not a clear strategy for green employee rewards. For example, employee suggestion programmes are not specific to environmental issues, though such programmes could involve employees in implementing feasible greener suggestions. Only company B provides financial recognition and rewards, whereas in the other organisations, reward and recognition are provided in other ways, such as gifts. There are no mechanisms for the greener performance evaluation in the studied companies; only in company $A$ there is a green performance evaluation for supervisors and line managers regarding their environmental performance when goals are achieved or exceeded. Respondents exposed the difficulties of developing a fair system for recognition and rewards for employees that have outstanding performance on environmental issues. This kind of barrier tends to reduce total involvement of employees.

Cross-referencing the cases studied in this research, it is clear that companies $A$ and $B$ have a more supportive GHRM strategy than company $C$, due to evidence of initiatives on greener performance evaluation and rewards. Still, neither of them has the full support of GHRM for developing a better fit between CSFs and GSCM. Thus, companies A and B perform a more advanced GHRM than company C.

\section{Discussions}

In this section, the four research prepositions will be discussed along with the main research outputs.

First, regarding proposition 1 (Companies with more proactive GSCM approaches will also have better-managed (SFs) and proposition 2 (Companies with less proactive GSCM approaches will also 
have less well-managed (SFs) and based on Carbone and Moatti (2011), it is possible to classify companies A, B and C in terms of GSCM proactivity (proactive, intermediate and less proactive). Companies A and B show a better adoption of GSCM, demonstrating that ISO14001 can help companies in becoming greener. Company $A$ is clearly the most proactive in terms of GSCM, mainly because it is adopting eco-design more consistently. Company $\mathrm{B}$ can be classified in the intermediate stage of GSCM proactivity. Finally, company $\mathrm{C}$ is just starting the adoption of GSCM; this company adopts GSCM but with less proactivity and intensity than companies $A$ and $B$. The institutional context is shown to play a major role in the adoption of GSCM and it tends to generate different GSCM approaches in terms of proactivity, as Carbone and Moatti (2011) confirm.

According to companies $A, B$ and $C$, pressure from new environmental legislation (forcing reverse logistics, for example) is a main driver for the adoption of GSCM. These findings confirm many studies on GSCM that concluded that external pressures play a major role in inducing GSCM adoption (Walker, Di Sisto, and McBain 2008; Zhu and Sarkis 2004). Imitation from other certifications (such as ISO 9001) proved to be useful in the adoption of some GSCM practices, confirming the main idea of Zhu, Tian, and Sarkis (2012). But results also show that institutional pressures should be combined with certain firms' resources that become CSFs.

We found that companies $A$ and $B$ are the two best cases for GSCM and are also the two companies that most effectively manage CSFs. On the other hand, company $C$ was worse than the other two in terms of managing CSFs for GSCM. Company $A$ deserves attention because it was the only one which has effectively managed the CSF competence for greener products and processes. As a consequence, there is a link between the proactivity of GSCM and the level of effective management of CSFs. Thus, this work confirms the literature on RBV (Barney 2001) applied to the natural environment (Hart and Dowell 2011), affirming that critical factors can facilitate better GSCM adoption (Sarkis, Zhu, and Lai 2011).

Its results also suggest that a better fit between environmental legislation and adoption of GSCM can be achieved by effectively managing CSFs. Thus, the'means-ends decoupling' phenomenon can be reduced by attention to CSFs, as discussed. Companies $A$ and $B$, with greater adoption of GSCM principles, are also the companies that best manage CSFs, achieving a better fit between 'plan' and 'outcome' by paying attention to CSFs (Wijen 2014).

The CSFs of top management commitment, relevant according to Bhattacharya et al. (2014), and supplier management, relevant according to Lee et al. (2015), are being well managed. However, some CSFs are not being adequately managed in the studied companies, and therefore have the potential to become problematic challenges. These factors include the following:

- the CSF of information management, confirming the challenge of managing green communication (Zutshi and Sohal 2004) and knowledge (O'Rourke 2014; Sarkis 2012) in a GSCM context;

- the CSF of measurement, confirming the challenges of measuring environmental performance (Green et al. 2012; Zhu and Sarkis 2004) and the verification of the performance of reverse logistics to reinstate materials and products to the manufacturer (Diabat, Khodaverdi, and Olfat 2013; Sarkis 1998; Srivastava 2007);

- The CSF of competence for greener products and processes, demonstrating that adopting a life cycle perspective is still a challenge (O'Rourke 2014; Wee and Quazi 2005; Zutshi and Sohal 2004);

- The CSFs of training and total involvement of employees may become potential barriers, which confirms previous research on green management reinforcing the relevance of green training and green behaviour at the workplace (Jackson, Schuler, and Jiang 2014; Renwick, Redman, and Maguire 2013; Jabbour 2013; Kim et al. 2014, and others).

Thus, it is possible to consider that both research propositions 1 and 2 are valid for this research because the level of GSCM proactivity is aligned with the effectiveness of managing CFSs Thus, companies with more proactive GSCM approaches will also have better managed CSFs, and companies with less proactive GSCM approaches will also have less well-managed CSFs.

Regarding proposition 3 (Companies with more strategic GSCM approaches and well-managed CSFs will also have more supportive GHRM aspects) and proposition 4 (Companies with less strategic GSCM approaches and less well-managed CSFs will also have less supportive GHRM aspects), in order to manage the above-listed CSFs adequately, GHRM aspects are relevant, confirming the potential of the integration between human aspects and operations management (Boudreau et al. 2003; Santos 2000). This is because companies with more proactive GSCM (for example, company A) are also the companies with more evidence although not optimal so far - in terms of support from GHRM for managing the CSF-GSCM link.

However, GHRM will require more intense involvement from HR departments to support line managers and supervisors in creating a clear GHRM strategy. In all organisations, the CSF green training is just partially implemented. Thus, green training should be improved because this is one of the most relevant factors in greening firms (Mohanty and Prakash 2014). As environmental training increases, so should the level of environmental management in companies (Jabbour 2013). Training is also relevant to companies adopting more advanced green practices (Sarkis, Gonzalez-Torre, and Adenso-Diaz 2010). Following the findings of Urtasun-Alonso et al. (2014), training is equally relevant in all the studied cases.

These organisations do not have a clear strategy for greener recruitment and selection, confirming the challenge of implementing these aspects of GHRM (Jackson, Schuler, and Jiang 2014). Environmental requirements are included in job descriptions only when those jobs involve tasks related to the environment or that may cause environmental impacts. The literature highlights that one good practice is to recruit and select candidates based on environmental requirements, because doing so may foster environmental innovations and generate a culture of environmental performance through environmentally friendly practices (Paillé et al. 2013; Renwick, Redman, and Maguire 2013; Sudin 2011).

Green rewards - for example, company suggestion programs - are not properly evaluated. Only company B provides financial recognition and rewards, whereas the other organisations provide rewards and recognition in other ways. Recognition and rewards, 
whether financial or not, are critical because they are tools that greatly encourage employees to be willing to generate environmental initiatives, resulting in a culture of environmental performance (Jackson et al. 2011; Paillé et al. 2013; Renwick, Redman, and Maguire 2013).

There are no mechanisms for green performance and evaluation in the studied companies; only in company $A$ is there a reward and recognition for line managers and supervisors for achieving or exceeding their environmental performance goals. This context confirms the arguments of Renwick, Redman, and Maguire (2013) and Jackson et al. (2011), which highlight the challenges of assessing and managing environmental performance in an accurate and fair way. However, recognition and reward are important elements for achieving environmental sustainability (Jabbour, Santos, and Nagano 2010).

As a consequence, it is possible to confirm the relevance of propositions 3 and 4, because there is evidence that companies $A$ and B (with more strategic GSCM approaches, well-managed CSFs and more supportive GHRM aspects) are different than company C, which has a less strategic GSCM approach, less well-managed CSFs, and less supportive GHRM aspects. Thus, in general, company $A$ is better than company $B$, which is better than company $C$ in terms of GSCM proactivity, effective management of CSFs and support from GHRM aspects.

Based on the discussion above and considering the RBV, this paper contributes to the literature on GSCM by showing that: companies should manage their GSCM proactivity, CSFs and support from GHRM practices; EMS and eco-design can be considered distinctive issues when adopting a more proactive GSCM, confirming Carbone and Moatti (2011); and companies need to better manage the CSFs of information management, measurement, training, competence for greener products and processes, and total involvement of employees. Companies with a special focus on these CSFs will probably have more success during the adoption of GSCM. Also, GHRM can help to adequately manage these CSFs using the following strategies: greener recruitment and selection, green training, greener performance evaluation and green rewards. As we studied focal companies, which are central in GSCM diffusion (Lee et al. 2014b), the adoption of these practices can have a positive effect throughout a supply chain. These GHRM aspects can help companies in emerging countries such as Brazil to achieve a better fit between the intention of GSCM practice adoption and the outcomes of this process, reducing the 'means-ends decoupling' phenomenon (Wijen 2014).

These results show managers what CSFs should be prioritised (Wee and Quazi 2005; Luthra et al. 2014; Mittal and Sangwan 2014) and suggest ways for better integrating human aspects and operations management (Boudreau et al. 2003; Santos 2000) with a focus on supply chain management (Lengnick-Hall, Lengnick-Hall, and Rigsbee 2013). The results also add practical insights from GSCM in the Brazilian manufacturing sector under emerging environmental legislation, and can be useful to analysing others emerging economies in similar contexts, completing a better picture of greening companies from BRICs. The findings also suggest the need for a more holistic and systemic approach when managing GSCM and related issues, because the validation of propositions 1, 2, 3 and 4 shows an aligned process.

\section{Conclusions}

With RBV as background, this work presented four main research prepositions and tested them based on evidence from three cases of Brazilian companies trying to adopt GSCM. The research results show that companies with more proactive GSCM tend to have a higher level of effectively managed of CSFs (especially competence for greener products and processes) and support from GHRM; on the other hand, companies with lower levels of GSCM proactivity tend to have fewer effectively managed CSFs and low support from GHRM aspects. This work also found CSFs that already are being well managed and others that deserve managerial attention (information management, measurement, competence for greener products and processes, training and total involvement of employees). Companies with better attention to these CSFs achieved better GSCM and environmental management results than those without attention to these CSFs. Attention to these CSFs can contribute to the creation of competitive advantages and a better fit between adopted practices and GSCM performance. Both institutional contexts and firms' resources were shown to be relevant, when combined, to promoting a more a proactive GSCM system.

Based on evidence from the less well-managed CSFs, we argue that GHRM presents a relevant opportunity for better integration between human aspects and operations management (Boudreau et al. 2003). As a consequence, managers with a clear GHRM strategy will have more success in appropriately managing CSFs mainly investing in green training, recruitment and selection, employee performance and rewards. A special focus on green training should be prioritised, because even though all of the companies are doing green training, it is not yet fully supported.

These results can be useful both for scholars, because they add evidence to a literature gap on RBV-GSCM (Sarkis, Zhu, and Lai 2011), and for managers, who can use these findings to prioritise and reinforce specific resources and strategies when implementing GSCM. These results can also be useful by policy-makers in emerging economies in considering the challenges of greening companies while drawing new green industrial policies.

\section{Disclosure statement}

No potential conflict of interest was reported by the authors.

\section{Funding}

This work was supported by the Conselho Nacional de Desenvolvimento Científico e Tecnológico [grant number 400101/2013-0], [grant number 303484/2013-6], and [grant number 304225/2013-4] and Fundação de Amparo à Pesquisa do Estado de São Paulo [grant number 2013/22380-0].

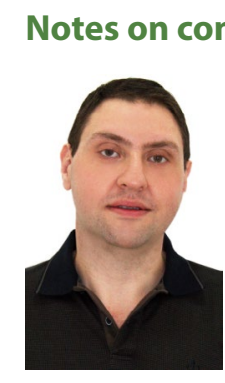

Charbel José Chiappetta Jabbour is an academic at the University of Stirling Management School, Centre for Advanced Management Education (CAME), Scotland-UK. He was a Professor (Associate III) at UNESP-Sao Paulo State Univ (2011-16) and USP-Univ of Sao Paulo (200811). He was supervisor of dozens of academics (MSc, PhDs, Post-Docs), and principal investigator of funded projects (FAPESP, CNPq "Science without Borders" and CAPES) while in Brazil. He was Director of an UNESP's PhD/MSc Programme (2013-2016). 


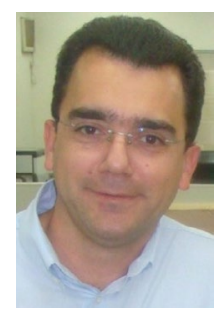

André Luis Mauricio is a manager and a consultant on marketing, sustainability and GSCM in Brazil. He also is a researcher within the Production Engineering Programme (Master and PhD) at UNESP - Sao Paulo State University, Faculty of Engineering, Bauru City - Sao Paulo, Brazil.

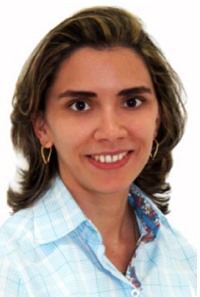

Ana Beatriz Lopes de Sousa Jabbour has worked at Design, Manufacture \& Engineering Management Department, University of Strathclyde Glasgow, Scotland-UK, since 2016. She was Associate Professor at UNESP - Sao Paulo State Univ (Brazil). She serves as Editor of Latin American J. of Manag. for Sustainable Development and has guest-edited Special Issues on Sustainable Engineering \& Man. (IJCCSM, IJSDWE, JClePro ...). She was the principal investigator of projects funded by FAPESP and CNPq "Science Without Borders".

\section{References}

Ab Talib, M. S., and S. Muniandy. 2013. "Green Supply Chain Initiatives in Malaysia: A Conceptual Critical Success Factors Framework." World Applied Sciences Journal 26 (2): 276-281.

Ageron, B., and A. Gunasekaran, and A. Spalanzani. 2012. “Sustainable Supply Management: An Empirical Study." International Journal of Production Economics 140 (1): 168-182.

Anfavea. 2014. Anuário da Indústria Automobilística Brasileira [Annual Report on the Brazilian Automotive Industry]. São Paulo, Brasil: Anfavea.

Babakri, K. A., R. A. Bennett, and M. Franchetti. 2003. "Critical Factors for Implementing ISO 14001 Standard in United States Industrial Companies." Journal of Cleaner Production 11 (7): 749-752.

Barney, J. B. 2001. "Resource-based Theories of Competitive Advantage: A Ten-year Retrospective on the Resource-based View." Journal of Management 27 (6): 643-650.

Bhattacharya, A., P. Mohapatra, V. Kumar, P. K. Dey, M. Brady, M. K. Tiwari, and S. S. Nudurupati. 2014. "Green Supply Chain Performance Measurement Using Fuzzy ANP-based Balanced Scorecard: A Collaborative Decisionmaking Approach." Production Planning \& Control 25 (8): 698-714.

Boudreau, J., W. Hopp, J. O. McClain, and L. J. Thomas. 2003. “On the Interface Between Operations and Human Resources Management." Manufacturing \& Service Operations Management 5 (3): 179-202.

Boynton, A. C., and R. W. Zmud. 1984. "An Assessment of Critical Success Factors." Sloan Management Review 25 (4): 17-27.

Büyüközkan, G., and G. Çifçi. 2012. "Evaluation of the Green Supply Chain Management Practices: A Fuzzy ANP Approach." Production Planning \& Control 23 (6): 405-418.

Carbone, V., and V. Moatti. 2011. "Towards Greener Supply Chains: An Institutional Perspective." International Journal of Logistics Research and Applications 14 (3): 179-197.

Carter, C. R., L. M. Ellram, L. Kaufmann, C. W. Autry, X. Zhao, and T. E. Callarman. 2014. "Looking Back and Moving Forward: 50 years of the Journal of Supply Chain Management." Journal of Supply Chain Management 50 (1): $1-7$.

Castro, B. H. R., D. C. Barros, and S. G. Veiga. 2013. "Baterias automotivas: panorama da indústria no Brasil, as novas tecnologias e como os veículos elétricos podem transformar o mercado global." [Automotive Batteries: The Brazilian Industry and how the Electric Car can Change the Global Market.] BNDES Setorial Automotivo 37: 443-396.

Chin, K. S., B. L. Chan, and P. K. Lam. 2008. "Identifying and Prioritizing Critical Success Factors for Coopetition Strategy." Industrial Management \& Data Systems 108 (4): 437-454.

CIA (Central Intelligence Agency). 2012. The World Factbook: Country Comparison - GDP (Purchasing Power Parity). Acesso em: dez. 10, 2013. Disponível em: https://www.cia.gov/library/publications/the-worldfactbook/rankorder/2001 rank.html

Croson, R., K. Schultz, E. Siemsen, and M. L. Yeo. 2013."Behavioral Operations: The State of the Field." Journal of Operations Management 31 (1-2): 1-5.
Diabat, A., R. Khodaverdi, and L. Olfat. 2013. "An Exploration of Green Supply Chain Practices and Performances in an Automotive Industry." The International Journal of Advanced Manufacturing Technology 68 (1-4): 949-961.

Garetti, M., G. Mummolo, and M. Taisch. 2012. "Sustainable Manufacturing: Trends and Research Challenges." Production Planning \& Control 23 (2-3): 83-104.

Genovese, A., S. C. L. Koh, N. Kumar, and P. K. Tripathi. 2014. “Exploring the Challenges in Implementing Supplier Environmental Performance Measurement Models: A Case Study." Production Planning \& Control 25 (13-14): 1198-1211.

Golicic, S. L., and C. D. Smith. 2013. "A Meta-analysis of Environmentally Sustainable Supply Chain Management Practices and Firm Performance." Journal of Supply Chain Management 49 (2): 78-95.

González-Benito, J., and Ó. González-Benito. 2006. “A Review of Determinant Factors of Environmental Proactivity." Business Strategy and the Environment 15 (2): 87-102.

Govindan, K., M. Kaliyan, D. Kannan, and A. N. Haq. 2014b. "Barriers Analysis for Green Supply Chain Management Implementation in Indian Industries Using Analytic Hierarchy Process." International Journal of Production Economics 147: 555-568.

Govindan, K., J. Sarkis, C. J. C. Jabbour, Q. Zhu, and Y. Geng. 2014a. "Ecoefficiency Based Green Supply Chain Management: Current Status and Opportunities." European Journal of Operational Research 233 (2): 293-298.

Green Jr, K. W., P. J. Zelbst, J. Meacham, and V. S. Bhadauria. 2012. "Green Supply Chain Management Practices: Impact on Performance." Supply Chain Management: An International Journal 17 (3): 290-305.

Grimm, J. H., J. S. Hofstetter, and J. Sarkis. 2014. "Critical Factors for Subsupplier Management: A Sustainable Food Supply Chains Perspective." International Journal of Production Economics 152: 159-173.

Gunasekaran, A., Z. Irani, and T. Papadopoulos. 2014. "Modelling and Analysis of Sustainable Operations Management: Certain Investigations for Research and applications." Journal of the Operational Research Society 65 (6): 806-823.

Gunasekaran, A., C. J. C. Jabbour, and A. B. L. Jabbour. 2014. "Managing Organizations for Sustainable Development in Emerging Countries: An Introduction." International Journal of Sustainable Development \& World Ecology 21 (3): 195-197.

Gunasekaran, A., and E. W. T. Ngai. 2012. "The Future of Operations Management: An Outlook and Analysis." International Journal of Production Economics 135 (2): 687-701.

Hart, S. L., and G. Dowell. 2011. "Invited Editorial: A Natural-resource-based View of the Firm Fifteen Years After." Journal of Management 37 (5): 1464 1479.

Hu, A. H., and C. W. Hsu. 2010. "Critical Factors for Implementing Green Supply Chain Management Practice: An Empirical Study of Electrical and Electronics Industries in Taiwan." Management Research Review 33 (6): 586-608.

Hui, I. K., A. H. Chan, and K. F. Pun. 2001. "A Study of the Environmental Management System Implementation Practices." Journal of Cleaner Production 9 (3): 269-276.

Jabbour, C. J. C. 2013. "Environmental Training in Organisations: From a Literature Review to a Framework for Future Research." Resources, Conservation and Recycling 74: 144-155.

Jabbour, A. B. L., and C. J. C. Jabbour. 2009. "Are Supplier Selection Criteria Going Green? Case Studies of Companies in Brazil." Industrial Management \& Data Systems 109 (4): 477-495.

Jabbour, A. B. L. S., C. J. C. Jabbour, J. Sarkis, and K. Govindan. 2014. "Brazil's New National Policy on Solid Waste: challenges and Opportunities." Clean Technologies and Environmental Policy 16 (1): 7-9.

Jabbour, C. J. C., A. B. L. S. Jabbour, A. A. Teixeira, and W. R. S. Freitas. 2012. "Environmental Development in Brazilian Companies: The Role of Human Resource Management." Environmental Development 3: 137-147.

Jabbour, C. J. C., F. C. A. Santos, and M. S. Nagano. 2010. "Contributions of HRM Throughout the Stages of Environmental Management: Methodological Triangulation Applied to Companies in Brazil." The International Journal of Human Resource Management 21 (7): 1049-1089.

Jabbour, C. J. C., A. A. Teixeira, and A. B. L. S. Jabbour. 2013. "Environmental Training In Organizations with ISO 14001 Certification: A Multiple Case Study and Identification of Co-evolution with Environmental Management." Production (Revista Produção) 23 (1): 80-94. 
Jackson, S. E., D. W. Renwick, C. J. C. Jabbour, and M. Müller-Camen. 2011. "State-of-the-art and Future Directions for Green Human Resource Management: Introduction to the Special Issue." Zeitschrift für Personalforschung (ZfP) 25 (2): 99-116.

Jackson, S. E., R. S. Schuler, and K. Jiang. 2014. "An Aspirational Framework for Strategic Human Resource Management." The Academy of Management Annals 8 (1): 1-56.

Kim, A., Y. Kim, K. Han, S. E. Jackson, and R. E. Ployhart. 2014. "Multilevel Influences on Voluntary Workplace Green Behavior Individual Differences, Leader Behavior, and Coworker Advocacy." Journal of Management, 0149206314547386.

Kim, J., and J. Rhee. 2012. "An Empirical Study on the Impact of Critical Success Factors on the Balanced Scorecard Performance in Korean Green Supply Chain Management Enterprises." International Journal of Production Research 50 (9): 2465-2483.

Koplin, J., S. Seuring, and M. Mesterharm. 2007. "Incorporating Sustainability into Supply Management in the Automotive Industry-The Case of the Volkswagen AG." Journal of Cleaner Production 15 (11-12): 1053-1062.

Lee, S. Y., R. D. Klassen, A. Furlan, and A. Vinelli. 2014b. "The Green Bullwhip Effect: Transferring Environmental Requirements Along a Supply Chain." International Journal of Production Economics 156: 39-51.

Lee, V. H., K. B. Ooi, A. Y. L. Chong, and B. Lin. 2015. "A Structural Analysis of Greening the Supplier, Environmental Performance and Competitive Advantage." Production Planning \& Control 26 (2): 116-130.

Leidecker, J. K., and A. V. Bruno. 1984. "Identifying and Using Critical Success Factors." Long Range Planning 17 (1): 23-32.

Lengnick-Hall, M. L., C. A. Lengnick-Hall, and C. M. Rigsbee. 2013. "Strategic Human Resource Management and Supply Chain Orientation." Human Resource Management Review 23 (4): 366-377.

Longoni, A., R. Golini, and R. Cagliano. 2014. "The role of New Forms of Work Organization in Developing Sustainability Strategies in Operations." International Journal of Production Economics 147: 147-160.

Luthra, S., D. Garg, and A. Haleem. 2014. "Critical Success Factors of Green Supply Chain Management for Achieving Sustainability in Indian Automobile Industry." Production Planning \& Control: 1-24. Ahead-ofprint.

Luthra, S., V. Kumar, S. Kumar, and A. Haleem. 2011. "Barriers to Implement Green Supply Chain Management in Automobile Industry Using Interpretive Structural Modeling Technique: An Indian Perspective." Journal of Industrial Engineering and Management 4 (2): 231-257.

Matheys, J., J. M. Timmermans, J. Van Mierlo, and S. Meyer. 2009. “Comparison of the Environmental Impact of Five Electric Vehicle Battery Technologies Using LCA." International Journal of Sustainable Manufacturing 1 (3): 318 329.

Mathiyazhagan, K., K. Govindan, A. NoorulHaq, and Y. Geng. 2013. "An ISM Approach for the Barrier Analysis in Implementing Green Supply Chain Management." Journal of Cleaner Production 47: 283-297.

Mittal, V. K., and K. S. Sangwan. 2014. "Development of a Model of Barriers to Environmentally Conscious Manufacturing Implementation." International Journal of Production Research 52 (2): 584-594.

Mohanty, R. P., and A. Prakash. 2014. "Green Supply Chain Management Practices in India: An Empirical Study". Production Planning \& Control 25 (16): 1322-1337.

Muduli, K., K. Govindan, A. Barve, and Y. Geng. 2013. "Barriers to Green Supply Chain Management in Indian Mining Industries: A Graph Theoretic Approach." Journal of Cleaner Production 47: 335-344.

Ngai, E. W. T., T. C. E. Cheng, and S. S. M. Ho. 2004. "Critical Success Factors of Web-based Supply-chain Management Systems: An Exploratory Study." Production Planning \& Control 15 (6): 622-630.

O'Rourke, D. 2014. "The Science of Sustainable Supply Chains." Science 344 (6188): 1124-1127.

Ogden, J. A. 2006. "Supply Base Reduction: An Empirical Study of Critical Success Factors." The Journal of Supply Chain Management 42 (4): 29-39.

Pagell, M., and A. Shevchenko. 2014. "Why Research in Sustainable Supply Chain Management Should Have no Future." Journal of Supply Chain Management 50 (1): 44-55.

Paillé, P., Y. Chen, O. Boiral, and J. Jin. 2013. "The Impact of Human Resource Management on Environmental Performance: An Employee-level Study." Journal of Business Ethics 121 (3): 451-466.
Patil, S. K., and R. Kant. 2013. "A Fuzzy DEMATEL Method to Identify Critical Success Factors of Knowledge Management Adoption in Supply Chain." Journal of Information \& Knowledge Management 12: 1-12.

Quazi, H. A. 1999. "Implementation of an Environmental Management System: The Experience of Companies Operating in Singapore." Industrial Management \& Data Systems 99 (7): 302-311.

Renwick, D., T. Redman, and S. Maguire. 2008, April. "Green HRM: A Review, Process Model, and Research Agenda." University of Sheffield Management School Discussion Paper 2008 (1): 1-46.

Renwick, D. W., T. Redman, and S. Maguire. 2013. "Green Human Resource Management: A Review and Research Agenda." International Journal of Management Reviews 15 (1): 1-14.

Rockart, J. F. 1978. "Chief Executives Define Their Own Data Needs." Harvard Business Review 57 (2): 81-93.

Routroy, S., and S. K. Pradhan. 2013. "Evaluating the Critical Success Factors of Supplier Development: A Case Study." Benchmarking: An International Journal 20 (3): 322-341.

Saá-Pérez, P. D., and J. M. Garcla-FalcÓn. 2002. "A Resource-based View of Human Resource Management and Organizational Capabilities Development." The International Journal of Human Resource Management 13 (1): 123-140.

Sambasivan, M., and N. Y. Fei. 2008. “Evaluation of Critical Success Factors of Implementation of ISO 14001 Using Analytic Hierarchy Process (AHP): A Case Study from Malaysia." Journal of Cleaner Production 16 (13): 14241433.

Santos, F. C. 2000. "Integration of Human Resource Management and Competitive Priorities of Manufacturing Strategy." International Journal of Operations \& Production Management 20 (5): 610-628.

Sarkis, J. 1998. "Evaluating Environmentally Conscious Business Practices." European Journal of Operational Research 107 (1): 159-174.

Sarkis, J. 2012. "A Boundaries and Flows Perspective of Green Supply Chain Management." Supply Chain Management: An International Journal 17 (2): 202-216.

Sarkis, J., P. Gonzalez-Torre, and B. Adenso-Diaz. 2010. “Stakeholder Pressure and the Adoption of Environmental Practices: The Mediating Effect of Training." Journal of Operations Management 28 (2): 163-176.

Sarkis, J., Q. Zhu, and K. H. Lai. 2011. "An Organizational Theoretic Review of Green Supply Chain Management Literature." International Journal of Production Economics 130 (1): 1-15.

Saturnino, A. N., and C. J. C. Jabbour. 2010. "Guidelines for Improving the Adoption of Cleaner Production in Companies Through Attention to Non-technical Factors: A Literature Review." African Journal of Business Management 4 (19): 4217-4229.

Schuler, R. S., and S. E. Jackson. 1987. "Linking Competitive Strategies with Human Resource Management Practices." The Academy of Management Executive 1 (3): 207-219.

Seuring, S., and M. Müller. 2008. "From a Literature Review to a Conceptual Framework for Sustainable Supply Chain Management." Journal of Cleaner Production 16 (15): 1699-1710.

Srivastava, S. K. 2007. "Green Supply-chain Management: A State-of-the-art Literature Review." International Journal of Management Reviews 9 (1): 53-80.

Subramanian, N., A. Gunasekaran, M. D. Abdulrahman, C. Liu, and D. Su. 2014. "Reverse Logistics in the Chinese Auto-Parts Firms: Implementation Framework Development Through Multiple Case Studies." International Journal of Sustainable Development \& World Ecology 21 (3): 223-234.

Sudin, S. 2011. "Strategic Green HRM: A Proposed Model that Supports Corporate Environmental Citizenship." International Proceedings of Economics Development \& Research 10: 1-12.

Testa, F., and F. Iraldo. 2010. "Shadows and Lights of GSCM (Green Supply Chain Management): Determinants and Effects of These Practices Based on a Multi-national Study." Journal of Cleaner Production 18 (10-11): 953962.

Urtasun-Alonso, A., M. Larraza-Kintana, C. García-Olaverri, and E. HuertaArribas. 2014. "Manufacturing Flexibility and Advanced Human Resource Management Practices." Production Planning \& Control 25 (4): 303-317.

Vazquez-Brust, D., and C. Liston-Heyes. 2010. "Environmental Management Intentions: An Empirical Investigation of Argentina's Polluting Firms." Journal of Environmental Management 91: 1111-1122. 
Voss, C., N. Tsikriktsis, and M. Frohlich. 2002. "'" Case research in Operations Management." International Journal of Operations \& Production Management 22 (2): 195-219.

Walker, H., L. Di Sisto, and D. McBain. 2008. "Drivers and Barriers to Environmental Supply Chain Management Practices: Lessons From the Public and Private Sectors." Journal of Purchasing and Supply Management 14 (1): 69-85.

Walker, H., S. Seuring, J. Sarkis, and R. Klassen. 2014. "Sustainable Operations Management: Recent Trends and Future Directions." International Journal of Operations \& Production Management 34 (5).

Wee, Y. S., H. A. and Quazi. 2005. "Development and Validation of Critical Factors of Environmental Management." Industrial Management \& Data Systems 105 (1): 96-114.

Wijen, F. 2014. "Means Versus Ends in Opaque Institutional Fields: Trading off Compliance and Achievement in Sustainability Standard Adoption." Academy of Management Review 39 (3): 302-323.

Wolf, J. 2011. "Sustainable Supply Chain Management Integration: A Qualitative Analysis of the German Manufacturing Industry." Journal of Business Ethics 102 (2): 221-235.
Wolf, J. 2013. "Improving the Sustainable Development of Firms: The Role of Employees." Business Strategy and the Environment 22 (2): 92-108.

Yin, R. K. 2009. Case Study Research: Design and Methods. New York: Sage.

Zhu, Q., and J. Sarkis. 2004. "Relationships Between Operational Practices and Performance Among Early Adopters of Green Supply Chain Management Practices in Chinese Manufacturing Enterprises." Journal of Operations Management 22 (3): 265-289.

Zhu, Q., J. Sarkis, and K. H. Lai. 2008. "Confirmation of a Measurement Model for Green Supply Chain Management Practices Implementation." International Journal of Production Economics 111 (2): 261-273.

Zhu, Q., Y. Tian, and J. Sarkis. 2012. "Diffusion of Selected Green Supply Chain Management Practices: An Assessment of Chinese Enterprises." Production Planning \& Control 23 (10-11): 837-850.

Zutshi, A., and A. S. Sohal. 2004. "Adoption and Maintenance of Environmental Management Systems: Critical Success Factors." Management of Environmental Quality: An International Journal 15 (4): 399-419. 